\title{
Corporate Financial Distress of Industry Level Listings in Vietnam
}

\author{
Duc Hong Vo ${ }^{1,2}$, Binh Ninh Vo Pham ${ }^{1}$, Chi Minh Ho ${ }^{1}$ and Michael McAleer ${ }^{2,3,4,5,6, *(\mathbb{C})}$ \\ 1 Business and Economics Research Group, Ho Chi Minh City Open University, Ho Chi Minh City 7000, \\ Vietnam; duc.vhong@ou.edu.vn (D.H.V.); binh.pvn@vnp.edu.vn (B.N.V.P.); chi.hm@ou.edu.vn (C.M.H.) \\ 2 Department of Finance, Asia University, Taichung 41354, Taiwan \\ 3 Discipline of Business Analytics, University of Sydney Business School, Sydney 2006, Australia \\ 4 Econometric Institute, Erasmus School of Economics, Erasmus University Rotterdam, \\ 3062 PA Rotterdam, The Netherlands \\ 5 Department of Economic Analysis and ICAE, Complutense University of Madrid, 28040 Madrid, Spain \\ 6 Institute of Advanced Sciences, Yokohama National University, Yokohama 240-8501, Japan \\ * Correspondence: michael.mcaler@gmail.com
}

Received: 13 August 2019; Accepted: 17 September 2019; Published: 22 September 2019

\begin{abstract}
Any critical analysis of the corporate financial distress of listed firms in international exchange would be incomplete without a serious dissection at the industry level, because of the different levels of risks concerned. This paper considers the financial distress of listed firms at the industry level in Vietnam over the last decade. Two periods are considered, namely during the Global Financial Crisis (GFC) (2007-2009) and post-GFC (2010-2017). The logit regression technique is used to estimate alternative models based on accounting and market factors. The paper also extends the analysis to include selected macroeconomic factors that are expected to affect the corporate financial distress of listed firms at the industry level in Vietnam. The empirical findings confirm that the corporate financial distress prediction model, which includes accounting factors with macroeconomic indicators, performs much better than alternative models. In addition, the evidence confirms that the GFC had a damaging impact on each sector, with the Health \& Education sector demonstrating the most impressive recovery post-GFC, and the Utilities sector recording a dramatic increase in bankruptcies post-GFC.
\end{abstract}

Keywords: listed firms; industry level; corporate financial distress; bankruptcy; distance to default; fundamentals; Global Financial Crisis; Vietnam

JEL Classification: F62; F65; G01; G31; G33; G34

\section{Introduction}

A key issue in the analysis of the success or failure of firms in corporate finance is that financial distress typically occurs in four sequential stages. The first stage is incubation of the firm's financial situation. In the second stage, management becomes aware of the firm's financial distress, in what is generally called financial embarrassment. The third stage is financial insolvency, in which the firm does not have sufficient funds to meet its financial obligations. Subsequently, insolvency occurs in the final stage of the so-called corporate financial distress cycle.

Various studies have been conducted over the past three decades to predict the corporate financial distress of listed firms in international exchanges. The first model, based on various accounting ratios, was developed by Beaver (1966). The author used a dichotomous classification test to determine financial ratios that were intended to predict bankruptcy. Some years later, a multivariate statistical 
model that could distinguish failed firms from non-failed firms was developed by Altman (1968). The author examined 22 financial ratios, divided into five categories, namely (1) profitability, (2) activity, (3) liquidity, (4) solvency, and (5) leverage. A multivariate discriminant analysis (MDA) was conducted based on these five categories to examine and highlight early warning indicators of corporate financial distress for listed firms.

Another school of empirical studies argued that the major causes of insolvency of listed firms were a decline in asset value, a reduction in liquidity, and a decrease in the ability to raise capital. This school of thought argued that business default had three components: (1) value of assets, (2) asset value of uncertain risks, and (3) financial leverage.

In response to this view, an options-based approach has been developed and widely adopted in the commercial world. Black and Scholes (1973) and Merton (1974) discuss the call-option theory, which is a fundamental theory behind a market-based approach. Their contingent claims approach has been widely used in predicting corporate default. Even though numerous empirical studies have been conducted on the corporate financial distress of listed firms, the entire market of all listed firms is the key focus of the analysis, especially for emerging markets, such as Vietnam and other ASEAN countries. Any critical analysis of the corporate financial distress of listed firms would be incomplete without a serious dissection at the industry level, because of the different levels of risks concerned.

This paper takes a different approach to the analysis by focusing on different sectors of the economy. The novelty and originality of the paper arises from a focus on, and empirical analysis of, listed firms at the industry level in a specific emerging market, namely Vietnam.

The structure of the remainder of the paper is as follows. Section 2 presents a summary of the relevant literature on the issue of corporate financial distress and bankruptcy. The alternative models that are considered are discussed and presented in Section 3. Section 4 discusses the data and definitions of the variables used in the empirical analysis. The empirical findings are presented and analyzed in Section 5, followed by some concluding remarks and policy prescriptions in Section 6.

\section{Literature Review}

The default risk literature has grown rapidly in recent years, both in the quality and quantity of research output. For purposes of predicting bankruptcies, both accounting-based and market-based approaches have strongly influenced the commercial world. Since the seminal contribution by Altman (1968), a large literature related to financial distress has emerged, with multivariate discriminant analysis (MDA) used to classify a set of financial ratios into five categories, namely: (i) profitability, (ii) activity, (iii) liquidity, (iv) solvency, and (v) leverage. Among others, Ohlson (1980) used the logit model, which reflects timing issues and applies less restrictive assumptions than does the MDA technique, to measure the default risk for 105 failed and 2058 non-failed firms from 1970 to 1976 in the USA.

Similarly, Zmijewski (1984) used accounting variables to measure the proportion of financial distress based on the probit regression model and random exogenous sampling. The accounting ratios are net income to total assets, total debts to total assets, and current assets to total liabilities. In Greece, Theodossiou (1991) used both the logit and probit models for the period 1975 to 1986 to identify early warning indicators of financial distress. The empirical results suggested that the logit model was superior to the probit model in indicating financial distress. Some previous papers have predicted future risk using accounting data, including Altman et al. (1977); Altman (2000, 2005); Uğurlu and Aksoy (2006), and Stanisic et al. (2013), among others.

Another stream of risk theory has concentrated on the market-based approach of Black and Scholes (1973) and Merton (1974). Future bankruptcy is predicted using the relationship between the asset value volatility and the debt ratio. The contingent claims approach used in this paper is a fundamental theory for a large number of credit risk models. In some recent studies, researchers used a structural model to measure the default risk, followed by an examination of the correlations between default risk and other variables. In a related development, Bharath and Shumway (2008) examined the precision of the option-based model. 
The structural model was compared with a "naïve" alternative model that did not use the default probability. The alternative model has been demonstrated to outperform the other models. The authors found that the structural model was not a sufficient statistic for purposes of the probability of default, whereas its associated functional forms were appropriate for forecasting the default probability. In a seminal contribution, Koutsomanoli-Filippaki and Mamatzakis (2009) calculated the Merton-type bank risk and used VAR analysis to examine the relationship between efficiency and risk. The impacts of one standard deviation shocks to the DD on inefficiency were found to be negative and substantial.

Similarly, Charitou et al. (2013) estimated the predictive accuracy of the Black-Scholes-Merton (BSM) bankruptcy model after expanding the model with the direct addition of market-observable returns to the company's market value. The outcome sheds new light on the simple model, incorporating the direct market-observable variables, which performed more strongly than did the relatively complicated model.

In a recent paper, Agrawal et al. (2016) used logistic regression and multiple discriminant analysis (MDA) with the Merton Distance-to-Default (DD) approach to match the bankruptcy and non-bankruptcy groups, and predicted the default of the listed firms in India. Although the Z-score was added to the model, the Distance-to-Default was still significant.

Vasicek (1984); Leland (2002); Crosbie and Bohn (2003); Delianedis and Geske (2003); Vassalou and Xing (2004), and Patel and Vlamis (2006), among others, have used the contingent claims approach to measure financial distress.

Trujillo-Ponce et al. (2014) showed that the comprehensive model, including market-based and accounting-based factors, was the most reliable model for predicting financial distress, compared with the Z-core and KMV-Merton model. Using 2186 credit default swaps (CDS) for the European market in both the pre-GFC (2002-2006) and GFC (2007-2009) periods, the comprehensive model was used to forecast the default probability in the volatile periods. The explanatory power of the models was found to be substantially higher during the GFC period.

Furthermore, Allen et al. (2011) measured the credit risk of 22 listed Canadian and Australian banks using the Value-at-Risk (VaR), Conditional VaR (CVaR), Distance-to-Default (DD), and Conditional Distanceto-Default (CDD) criteria, in the pre-GFC (2002-2006) and GFC (2007-2008) periods. Both countries showed a considerable increase in the probability of default between the pre-GFC and GFC periods.

Subsequently, Allen and Powell (2012) applied the same VaR, CVaR, DD and CDD criteria to exam the default risk for all sectors forming part of the Australian All Ords Index, which includes the 500 largest listed companies and 58 commercial banks, for the pre-GFC (2000-2006) and GFC (2007-2008) periods. Almost all the industries displayed a poorer performance during the GFC period.

Byström et al. (2005) examined the relationship between the default risk of the SET50 firm index on the Stock Exchange of Thailand (SET), as well as firm-specific characteristics during the Asian crisis 1996-1998 and post-Asian crisis periods, using the Merton model. The authors found that the financial distress rose rapidly, and noted the contrasting performance among the sectors during the Asian crisis period. The highest risk was found in the Finance and securities sector, whereas the lowest risk was found in the Building and furnishing material sector.

\section{Model Specifications}

To capture the market-based information, the modified Distance-to-Default (DD) model derived by Byström (2006) is used in the empirical analysis. The foundation of the market-based approach is from the Kealhofer, McQuown, and Vasicek (KMV)—Merton (1974) model, which was developed based on the option theory of Black and Scholes (1973). Specifically, the closed relationship between the market value of equity and the market value of assets are expressed as below:

$$
\begin{gathered}
\mathrm{E}=\mathrm{VN}\left(\mathrm{d}_{1}\right)-\mathrm{e}^{-\mathrm{rT}} \mathrm{F} \mathrm{Nd}_{2} \\
\mathrm{~d}_{1}=\frac{\ln \left(\frac{\mathrm{V}}{\mathrm{F}}\right)+\left(\mathrm{r}+0.5 \sigma_{\mathrm{v}}^{2}\right) \mathrm{T}}{\sigma_{\mathrm{v}} \sqrt{\mathrm{T}}}
\end{gathered}
$$




$$
\mathrm{d}_{2}=\mathrm{d}_{1}-\sigma_{\mathrm{v}} \sqrt{\mathrm{T}}
$$

where:

E: Market value of the firm's equity

V: Market value of the firm's assets

F: Face value of the firm's debt

r: Risk-free rate

T: Time to maturity of the firm's debt

$\mathrm{N}$ : Cumulative standard normal distribution function

$\sigma_{\mathrm{E}}$ : Volatility of the firm's equity

The relationship between the equity volatility and volatility of the firm's value is expressed as follows:

$$
\sigma_{\mathrm{E}}=\left(\frac{\mathrm{V}}{\mathrm{E}}\right) \mathrm{N}\left(\mathrm{d}_{1}\right) \sigma_{\mathrm{v}}
$$

Solving the above two non-linear equations gives the firm's value, $\mathrm{V}$, and its volatility, $\sigma_{v}$ and the face value of the debt (F). The Distance-to-Default is established using the following expression:

$$
\mathrm{DD}_{\text {Merton }}=\frac{\ln \left(\frac{\mathrm{V}}{\mathrm{F}}\right)+\left(\mu-0.5 \sigma_{\mathrm{v}}^{2}\right) \mathrm{T}}{\sigma_{\mathrm{v}} \sqrt{\mathrm{T}}}
$$

Nevertheless, the KMV model is based on several stringent assumptions that seem to lack empirical support. As such, the original model needs to be modified to make it more suitable for emerging markets such as Vietnam. In particular, the default probability should be modelled using three parameters, namely the book value of debt, market value, and volatility of equity.

The model is based on the following three assumptions:

(i) Drift term $\left(\mu-0.5 \sigma_{\mathrm{v}}^{2}\right) \mathrm{T}$ is small, or close to zero;

(ii) $\mathrm{N}(\mathrm{d} 1)$ is assumed to be equal to unity;

(iii) Book value of debt is assumed to be the accounting leverage ratio.

Depending on the first assumption, the drift term equals zero or the maturity of liability is a year. The traditional Merton model is reduced as follows:

$$
\mathrm{DD}=\frac{\ln \left(\frac{\mathrm{V}}{\mathrm{F}}\right)}{\sigma_{\mathrm{V}}}
$$

From Equation (4), we replace $\sigma_{\mathrm{v}}=\left(\frac{\mathrm{E}}{\mathrm{v}}\right) \sigma_{\mathrm{E}}$ and the second assumption of $\mathrm{N}\left(\mathrm{d}_{1}\right)=1$ into Equation (6). We have:

$$
\mathrm{DD}=\frac{\ln \left(\frac{\mathrm{V}}{\mathrm{F}}\right)}{\left(\frac{\mathrm{E}}{\mathrm{v}}\right) \sigma_{\mathrm{E}}}
$$

In the final assumption, the leverage ratio is presented as $\mathrm{L}=\frac{\mathrm{F}}{\mathrm{V}}$. The DD model is restructured as follows (Pham et al. 2018):

$$
\mathrm{DD}_{\text {Adjusted Merton }}=\frac{\ln (1 / \mathrm{L})}{\sigma_{\mathrm{E}}(1-\mathrm{L})}=\frac{\ln (\mathrm{L})}{\sigma_{\mathrm{E}}(\mathrm{L}-1)}
$$

where:

Leverage ratio, $\mathrm{L}=\frac{\mathrm{F}}{(\mathrm{E}+\mathrm{F})}$, is calculated according to the market value of equity $(\mathrm{E})$ and the book value of debt $(\mathrm{F})$,

$\sigma_{\mathrm{E}}$ is the volatility of firm equity. 
The Cumulative Normal Distribution is used to measure the Expected Default Frequency (EDF) from the calculated DD value. The final result will be mapped into the S\&P rating, as discussed in Lopez (2004).

Three levels of financial distress are defined, as follows:

(1) $\operatorname{EDF}(\%) \leq 0.52 \%$ : Safe zone, where firms have a healthy financial foundation, with no risk of bankruptcy;

(2) $0.52 \%<\operatorname{EDF}(\%) \leq 6.94 \%$ : Grey zone, or warning zone, where the financial exposure is at a low level of potential bankruptcy;

(3) $\operatorname{EDF}(\%)>6.94 \%$ : Bankruptcy zone, or dangerous zone, where the default probability is at a high level.

\section{Data, ROC Curve and Definition of Variables}

\subsection{Data and ROC Curve}

Data for a sample of approximately 800 listed firms on the Ho Chi Minh Stock Exchange (HOSE), and Hanoi Stock Exchange (HNX), for the period 2007 to 2017, were obtained from Bloomberg for all 10 industries, as well as from the World Bank (2016) for the macroeconomic variables. Two sub-samples are considered in the empirical analysis, namely the GFC (2007-2009) and post-GFC (2010-2017) periods.

The literature review shows that both the accounting-based and market-based models have commendable features, but also suffer from limitations. This paper uses a comprehensive model that includes accounting, market and macroeconomic indicators to determine whether the performance of the comprehensive model can be improved. In particular, a key difference in this paper relative to other empirical studies is the focus on various sectors and industries in Vietnam. In the following sections, the Receiver Operating Characteristics (ROC) Curve and relevant $R^{2}$ checks are used to examine the efficiency of the model. In particular, the Area Under the ROC Curve (AUC) is used in assessing alternative ranking methodologies.

This powerful technique involves direct estimation of predictive accuracy for the logit regression. Chava and Jarrow (2004); Vassalou and Xing (2004); and Agarwal and Taffler (2008) state that the disparity in the cutoff probability is a major trait of the ROC curve. The ROC curve draws the true positive rate, or the percentage of defaults, that are classified accurately as defaults by the model on the $y$-axis, against the false positive rate, or the percentage of defaults that is classified mistakenly by the model, on the $x$-axis as the threshold of bankruptcy.

The AUC estimates the predictive accuracy of the model, with an accuracy ratio that is less than 0.5 representing a neglected model, and a ratio that is approximately 1 demonstrating a perfectly fitting model. Two additional methods for comparing the performance of the estimated models are Cox and Snell's $R^{2}$ and Nagelkerke's $R^{2}$, as discussed in Cox and Snell (1989) and Nagelkerke (1991), respectively. These checks are based on a similar concept to the calculation of $R^{2}$ for the linear regression model in measuring the goodness-of-fit of an empirical model.

\subsection{Dependent Variable}

Corporate financial distress is defined as a condition whereby a company is not able to meet its financial obligations or commitments, and is therefore a process in which a healthy company is transformed to one that may be approaching bankruptcy. Firms are called unhealthy when their operational profitability is not sufficient to meet their financial obligations. Asquith et al. (1994) stress that the capability of repaying the financial debt of a business is a critical problem. Using this concept, the variance between the current maturities of long-term debt and a company's cash flow is used in Whitaker (1999) analysis.

Similarly, Pindado et al. (2008) and Tinoco and Wilson (2013) present two requirements for recognizing financial distress. The first requirement is the deficit between the earnings before interest, tax, and depreciation (EBITDA), and interest expenses. When the financial obligations might not be covered 
by the returns, the firm faces considerable financial risks. The second requirement is the negative growth of the market value of a firm's equity for two consecutive years. The firm size, together with the volatility of the market value of their equity, contribute to detecting the financial distress of a company.

However, almost all Vietnamese listed firms are relatively small by world standards. For example, the economic shock or sudden debt requirements arising from short term economic downturns is unlikely to be met because the current levels of capital of firms may not be sufficient to meet and repay the financial obligations. Consequently, for Vietnam, the variance between the return earnings before interest and taxes and interest expenses (that is, the Interest Coverage Ratio) is used to estimate the probability of default for each year, with the ratio constrained to lie within the range $[0,1]$.

The firms identified as being financially healthy are assigned the value of 0 , while financially distressed firms are accorded the value of 1 . Financial distress for each firm is examined for each year in the 10-year period 2007-2017 for which the relevant data are available. Consequently, each firm in the empirical analysis has 10 observations. Tables 1 and 2 present the results of classifications in two stages: 1572 observations are classified as the non-default group (accounting for 86 percent of the observations) in the GFC period (2007-2009), and 3718 observations belonging to the non-default group (accounting for 73 percent of the observations) in the post-GFC period (2010-2017). The correlation matrices among variables are presented in Appendices A and B.

Table 1. Descriptive statistics of dependent variable during GFC (2007-2009).

\begin{tabular}{cccc}
\hline Classify & Frequency & $\%$ & Cumulative \\
\hline 0 & 1367 & 86.96 & 86.96 \\
1 & 205 & 13.04 & 100 \\
Total & 1572 & 100 & \\
\hline \multicolumn{4}{c}{ Source: Authors' analyses. }
\end{tabular}

Source: Authors' analyses.

Table 2. Descriptive statistics of dependent variable post-GFC (2010-2017).

\begin{tabular}{cccc}
\hline Classify & Frequency & $\%$ & Cumulative \\
\hline 0 & 3718 & 73.23 & 73.23 \\
1 & 1359 & 26.77 & 100 \\
Total & 5077 & 100 & \\
\hline \multicolumn{4}{c}{ Source: Authors' analyses. }
\end{tabular}

\subsection{Explanatory Variables}

\subsubsection{Accounting Variables}

We construct the model using a range of selected explanatory variables, including financial liquidity, profitability, productivity of assets, and solvency, that have appeared in previous empirical studies (see, for example, Altman (1968, 2000, 2005); Taffler (1984); Shumway (2001); Hillegeist et al. (2004); and Wu et al. (2010), among others).

The variables are given as follows:

(i) the financial, defined as working capital/total assets (WC/TA), is frequently used as a measure of corporate liquidity, and provides strong evidence of existing corporate defaults;

(ii) the financial ratio, defined as retained earnings over total assets (RE/TA), measures the cumulative profitability over time, with young firms usually possessing a low value of RE/TA as they have not yet had sufficient time to accumulate substantial returns;

(iii) the financial ratio, defined as earnings before interest and taxes over the total asset (EBIT/TA), indicates the true productivity of a firm's assets;

(iv) the ability to meet financial obligations is based on the financial ratio, defined as the book value of equity over the total liability (BVE/TL). 
These four accounting variables are expected to have individual negative effects on the financial distress of listed firms in international exchanges.

\subsubsection{Market Variables}

A set of market variables contributing to enhance the predictive power of the distress model is also used. The first market variable is the stock price (PRICE), as discussed in Rees (1995) and Beaver et al. (2005). The second variable is the firm size, or the market value of equity (MVE), as mentioned in Agarwal and Taffler (2008). The third market variable is the volatility of equity $\left(\sigma_{\mathrm{E}}\right)$. Zhang et al. (2009) indicate that the higher is the equity volatility, the greater will be the asset volatility leading to financial default. The final market variable is the leverage ratio (LEVERAGE), which reflects the level of debt used (see Byström 2006). This ratio is computed as the total debt relative to the total market value of equity and total debt.

\subsubsection{Macroeconomic Variables}

In this paper, two macroeconomic variables, namely the short-term Treasury Bill one-year rate (SHTBRDEF) and Inflation rate, are included. This choice is carefully considered from the list of eleven macroeconomic indicators generally used in other empirical studies. The short-term Treasury Bill one-year rate is a proxy for the interest rate that may strongly affect industrial firms, as discussed in Ali and Daly (2010); Badar and Javid (2013), and Chaibi and Ftiti (2015). An increase in the Treasury Bill one-year rate leads to an increase in the interest rate, a higher cost of financial expenses, and a dramatic increase in the company's probability of default.

Another macroeconomic indicator that is included in the final model is Inflation. A high inflation rate increases the prices of goods and services, thereby leading to an increase in the number of firms that end up in financial difficulties (for further details, see Demirgüç-Kunt and Detragiache (1998); Rinaldi and Sanchis-Arellano (2006); Mare (2015), and Ćurak et al. (2013)).

In summary, a combination of the accounting-based, market-based and macroeconomic variables impacting on the financial distress is used to capture various aspects of the default risk. Thus, the comprehensive model can be presented, as follows:

$$
\begin{gathered}
Y=\beta_{1} \frac{W C}{T A}+\beta_{2} \frac{R E}{T A}+\beta_{3} \frac{E B I T}{T A}+\beta_{4} \frac{B V E}{T L}+\beta_{5} \ln (M V E)+\beta_{6} \ln L E V E R A G E \\
+\beta_{7} \sigma_{E}+\beta_{8} P R I C E+\beta_{9} \text { Treasury Bill }+\beta_{10} \text { Inflation }+\varepsilon
\end{gathered}
$$

where:

$Y$ (Classify): Binary variable denoting non-default $(Y=0)$ and default $(Y=1)$

$\frac{W C}{T A}$ : Working Capital to Total Assets

$\frac{R E}{T A}$ : Retained Earnings to Total Assets

$\frac{E B I T}{T A}$ : Earnings Before Interest and Taxes (operating profit) to Total Assets

$\frac{B V E}{T L}$ : Book Value of Equity to Total Liabilities

$M V E$ : Market Value of Equity

LEVERAGE: Leverage ratio

$\sigma_{\mathrm{E}}:$ Volatility of Equity

PRICE : Stock Price

Treasury Bill: Short-term Treasury Bill one-year rate

Inflation: Inflation rate

$\varepsilon$ : Random error term.

Tables 3 and 4 report the summary statistics for the explanatory variables in both the GFC and post-GFC periods. The descriptive statistics include the mean, standard deviation, minimum and maximum for WCTA (working capital over total assets), RETA (retained earnings over total assets), EBITTA (earnings before interest and taxes (operating profit) to total assets), BVETA (book value of 
equity to total liabilities), $M V E$ (market value of firm equity), PRICE (stock price), VOL_MVE (volatility of the market value of equity), LEVERAGE (leverage ratio), INFLATION (inflation), and SHTBRDEF (short-term Treasury Bill one-year rate).

Table 3. Summary statistics for explanatory variables during the GFC (2007-2009).

\begin{tabular}{lccccc}
\hline \multicolumn{1}{c}{ Variable } & Obs. & Mean & Std. Dev. & Min & Max \\
\hline Working capital/total asset & 1572 & 0.252 & 0.224 & -0.499 & 0.998 \\
Retained earnings/asset & 1572 & 0.061 & 0.067 & -0.437 & 0.422 \\
EBIT/Total assets & 1572 & 0.060 & 0.074 & -0.129 & 0.664 \\
Book value of equity/Total liabilities & 1572 & 0.712 & 0.284 & 0.001 & 1.000 \\
Price & 1572 & 30594 & 33927 & 317 & 304820 \\
Ln (Market value of equity) & 1572 & 12.221 & 2.025 & 6.994 & 22.284 \\
Volatility of equity & 1572 & 4940 & 10,900 & 20.123 & 336,000 \\
Leverage & 1572 & 1.413 & 1.313 & 0.003 & 12.551 \\
Inflation & 1572 & 12.9 & 7.2 & 7.3 & 23.1 \\
Treasury Bill & 1572 & 8.1 & 3.3 & 4.2 & 12.1 \\
\hline
\end{tabular}

Source: Authors' analyses.

Table 4. Summary statistics for explanatory variables post-GFC (2010-2017).

\begin{tabular}{lccccc}
\hline \multicolumn{1}{c}{ Variable } & Obs. & Mean & Std. Dev. & Min & Max \\
\hline Working capital/total asset & 5077 & 0.198 & 0.243 & -1.362 & 1.000 \\
Retained earnings/asset & 5077 & 0.032 & 0.148 & -2.760 & 0.529 \\
EBIT/Total assets & 5077 & 0.024 & 0.071 & -2.290 & 0.981 \\
Book value of equity/Total liabilities & 5077 & 0.649 & 0.313 & -0.568 & 1.000 \\
Price & 5077 & 17,300 & 18,740 & 400 & 202,000 \\
Ln (Market value of equity) & 5077 & 12.129 & 1.872 & 6.947 & 21.136 \\
Volatility of equity & 5077 & 6836 & 98,955 & 18.4 & 530,000 \\
Leverage & 5077 & 0.886 & 1.012 & 0.004 & 11.315 \\
Inflation & 5077 & 7.4 & 5.4 & 0.9 & 18.6 \\
Treasury Bill & 5077 & 7.5 & 3.1 & 4.0 & 12.4 \\
\hline
\end{tabular}

Source: Authors' analyses.

\section{Empirical Results and Analysis}

This paper considers the financial distress of Vietnamese listed firms under different economic circumstances and for two sub-periods, namely during the GFC (2007-2009) and post-GFC (2010-2017) periods. Tables 5 and 6 present the results of a logit regression of financial distress for both the GFC and post-GFC periods. Alternative models have been used to consider the separate effects from accounting factors, market-based factors, and macroeconomic factors on financial distress and bankruptcy for the Vietnamese listed firms. In addition, on account of the high correlation between Inflation and the Short-term Treasury Bill one-year rate, various models are estimated to try to ameliorate the correlation among the variables.

The following models are estimated in the paper:

(1) Model 1: all explanatory accounting variables;

(2) Model 2: all market variables;

(3) Model 3: all accounting variables plus inflation;

(4) Model 4: all accounting variables plus the short-term Treasury Bill one-year rate;

(5) Model 5: all market variables plus inflation;

(6) Model 6: all market variables plus the short-term Treasury Bill one-year rate;

(7) Model 7: all accounting and market variables plus inflation;

(8) Model 8: all accounting and market variables plus the short-term Treasury Bill one-year rate. 
Substantial differences can be observed between the two periods in relation to the statistical significance of some explanatory variables. During the GFC period, Models 3 and 4 have only one accounting variable and two macroeconomic indicators that are statistically significant at significance levels of 1 per cent to 10 per cent.

The earnings before interest and taxes over the total asset (EBIT/TA) variable has a negative impact, which represents the productivity of the company's assets, excluding the tax and leverage components or the earning power of the asset. This highlights that the higher is the level of EBIT, the higher is its performance, and therefore the lower is the probability of default.

Two macroeconomic indicators, including the inflation rate and short-term Treasury Bill one-year rate, have positive impacts. The higher is the value of inflation indicates the higher is the likelihood of financial distress. Surprisingly, these variables remain unchanged in relation to the signs and levels of significance after the GFC crisis. In particular, all of the accounting variables are statistical significant in the post-GFC period, including the net financial liquidity of the firm's assets (W C/TA), profitability (RE/TA), productivity of the company's assets (EBIT/TA), and the capability of covering the financial $\operatorname{debt}(\mathrm{BVE} / \mathrm{TL})$.

For the market-based approach, as presented in Models 5 and 6, there is no evidence of the relationship between the market variables and the default probability during the GFC. However, three market variables, including Price (PRICE), Market value of equity (MVE), and the Leverage ratio (LEVERAGE), have significant effects on financial distress in the post-GFC period.

Tables 7 and 8 present measures of model performance for the eight models for both the GFC and post-GFC periods. All of the models are found to be useful in measuring financial distress for the listed firms in Vietnam because of the high accuracy ratio ( $A R>0.5)$. The best model for the two periods is Model 3, which includes the accounting and macroeconomic variables, with the highest AR value of 0.9075 (GFC) and 0.9395 (post-GFC). Furthermore, two critical checks of the logistic regression, namely Nagelkerke's $R^{2}$ and Cox and Snell's $R^{2}$, confirm that the best empirical model in both periods is Model 3.

Table 5. Financial distress of Vietnamese listed firms during GFC (2007-2009).

\begin{tabular}{|c|c|c|c|c|c|c|c|c|}
\hline Variable & Model 1 & Model 2 & Model 3 & Model 4 & Model 5 & Model 6 & Model 7 & Model 8 \\
\hline WCTA & $\begin{array}{l}-0.03 \\
(0.05)\end{array}$ & & $\begin{array}{c}-0.161 \\
(0.28)\end{array}$ & $\begin{array}{c}-0.142 \\
(0.25)\end{array}$ & & & $\begin{array}{c}-0.198 \\
(0.34)\end{array}$ & $\begin{array}{c}-0.194 \\
(0.34)\end{array}$ \\
\hline RETA & $\begin{array}{c}-3.813 \\
(1.49)\end{array}$ & & $\begin{array}{c}-3.867 \\
(1.46)\end{array}$ & $\begin{array}{c}-3.446 \\
(1.33)\end{array}$ & & & $\begin{array}{c}-3.193 \\
(1.17)\end{array}$ & $\begin{array}{c}-3.093 \\
(1.15)\end{array}$ \\
\hline EBITTA & $\begin{array}{c}-97.532 \\
(10.70)^{* * *}\end{array}$ & & $\begin{array}{l}-100.221 \\
(10.36)^{* * *}\end{array}$ & $\begin{array}{c}-98.611 \\
(10.50)^{* * *}\end{array}$ & & & $\begin{array}{l}-100.968 \\
(10.26)^{* * *}\end{array}$ & $\begin{array}{c}-99.567 \\
(10.38)^{* * *}\end{array}$ \\
\hline BVETL & $\begin{array}{l}0.168 \\
(0.41)\end{array}$ & & $\begin{array}{l}0.155 \\
(0.36)\end{array}$ & $\begin{array}{c}0.16 \\
(0.38)\end{array}$ & & & $\begin{array}{l}0.186 \\
(0.37)\end{array}$ & $\begin{array}{l}0.183 \\
(0.37)\end{array}$ \\
\hline PRICE & & $\begin{array}{c}0.000 \\
(1.94)^{*}\end{array}$ & & & $\begin{array}{l}0.000 \\
-1.53\end{array}$ & $\begin{array}{l}0.000 \\
-0.94\end{array}$ & $\begin{array}{l}0.000 \\
-0.16\end{array}$ & $\begin{array}{l}0.000 \\
-0.23\end{array}$ \\
\hline MVE & & $\begin{array}{l}0.102 \\
(1.44)\end{array}$ & & & $\begin{array}{l}0.108 \\
(1.51)\end{array}$ & $\begin{array}{l}0.095 \\
(1.31)\end{array}$ & $\begin{array}{l}-0.055 \\
(0.70)\end{array}$ & $\begin{array}{c}-0.064 \\
(0.83)\end{array}$ \\
\hline VOL_MVE & & $\begin{array}{l}0.000 \\
(0.33)\end{array}$ & & & $\begin{array}{l}0.000 \\
(0.26)\end{array}$ & $\begin{array}{l}0.000 \\
(0.22)\end{array}$ & $\begin{array}{l}0.000 \\
(0.29)\end{array}$ & $\begin{array}{l}0.000 \\
(0.32)\end{array}$ \\
\hline LEVERAGE & & $\begin{array}{c}-0.173 \\
(1.60)\end{array}$ & & & $\begin{array}{c}-0.167 \\
(1.53)\end{array}$ & $\begin{array}{c}-0.143 \\
(1.30)\end{array}$ & $\begin{array}{c}-0.027 \\
(0.19)\end{array}$ & $\begin{array}{c}-0.011 \\
(0.08)\end{array}$ \\
\hline INFLATION & & & $\begin{array}{c}0.039 \\
(2.66)^{* * * *}\end{array}$ & & $\begin{array}{c}0.024 \\
(1.88)^{*}\end{array}$ & & $\begin{array}{c}0.036 \\
(2.34)^{* *}\end{array}$ & \\
\hline SHTBRDEF & & & & $\begin{array}{c}0.095 \\
(2.54)^{* *}\end{array}$ & & $\begin{array}{c}0.094 \\
(2.79)^{* * *}\end{array}$ & & $\begin{array}{c}0.093 \\
(2.16)^{* *}\end{array}$ \\
\hline _cons & $\begin{array}{l}0.004 \\
(0.01)\end{array}$ & $\begin{array}{c}-3.525 \\
(4.37) * * *\end{array}$ & $\begin{array}{c}-0.472 \\
(1.33)\end{array}$ & $\begin{array}{l}-0.818 \\
(1.84)^{*}\end{array}$ & $\begin{array}{c}-4.006 \\
(4.61)^{* * *}\end{array}$ & $\begin{array}{c}-4.475 \\
(4.90)^{* * * *}\end{array}$ & $\begin{array}{l}0.257 \\
(0.26)\end{array}$ & $\begin{array}{c}-0.055 \\
(0.05)\end{array}$ \\
\hline Insig2u_cons & $\begin{array}{l}0.057 \\
(0.09)\end{array}$ & $\begin{array}{c}1.127 \\
(4.48)^{* * * *}\end{array}$ & $\begin{array}{l}0.291 \\
(0.51)\end{array}$ & $\begin{array}{l}0.203 \\
(0.35)\end{array}$ & $\begin{array}{c}1.184 \\
(4.68)^{* * *}\end{array}$ & $\begin{array}{c}1.223 \\
(4.84)^{* * * *}\end{array}$ & $\begin{array}{l}0.333 \\
(0.59)\end{array}$ & $\begin{array}{l}0.264 \\
(0.46)\end{array}$ \\
\hline $\mathrm{N}$ & 1572 & 1572 & 1572 & 1572 & 1572 & 1572 & 1572 & 1572 \\
\hline
\end{tabular}

Note: Standard errors in parentheses: ${ }^{* * *} p<0.01,{ }^{* *} p<0.05,{ }^{*} p<0.1$. Source: Authors' analyses. 
Table 6. Financial distress of Vietnamese listed firms post-GFC (2010-2017).

\begin{tabular}{|c|c|c|c|c|c|c|c|c|}
\hline Variable & Model 1 & Model 2 & Model 3 & Model 4 & Model 5 & Model 6 & Model 7 & Model 8 \\
\hline WCTA & $\begin{array}{c}-0.91 \\
(2.71)^{* * *}\end{array}$ & & $\begin{array}{c}-0.883 \\
(2.60)^{* * * *}\end{array}$ & $\begin{array}{c}-0.878 \\
(2.58)^{* * *}\end{array}$ & & & $\begin{array}{l}-0.866 \\
(2.54)^{* *}\end{array}$ & $\begin{array}{l}-0.856 \\
(2.51)^{* *}\end{array}$ \\
\hline RETA & $\begin{array}{c}-2.617 \\
(4.31)^{* * *}\end{array}$ & & $\begin{array}{c}-3.048 \\
(4.71)^{* * *}\end{array}$ & $\begin{array}{c}-3.119 \\
(4.78) * * *\end{array}$ & & & $\begin{array}{c}-2.822 \\
(4.28)^{* * * *}\end{array}$ & $\begin{array}{c}-2.834 \\
(4.31)^{* * *}\end{array}$ \\
\hline EBITTA & $\begin{array}{c}-181.231 \\
(23.00)^{* * *}\end{array}$ & & $\begin{array}{l}-185.327 \\
(22.79) * * *\end{array}$ & $\begin{array}{l}-186.046 \\
(22.80)^{* * *}\end{array}$ & & & $\begin{array}{c}-184.921 \\
(22.58)^{* * *}\end{array}$ & $\begin{array}{c}-185.308 \\
(22.61)^{* * * *}\end{array}$ \\
\hline BVETL & $\begin{array}{c}-0.652 \\
(2.44)^{* *}\end{array}$ & & $\begin{array}{c}-0.665 \\
(2.45)^{* *}\end{array}$ & $\begin{array}{c}-0.676 \\
(2.49) * *\end{array}$ & & & $\begin{array}{c}-0.973 \\
(3.07)^{* * *}\end{array}$ & $\begin{array}{c}-0.965 \\
(3.04)^{* * *}\end{array}$ \\
\hline PRICE & & $\begin{array}{c}0.000 \\
(6.19)^{* * *}\end{array}$ & & & $\begin{array}{c}0.000 \\
(6.29)^{* * * *}\end{array}$ & $\begin{array}{c}0.000 \\
(6.15)^{* * *}\end{array}$ & $\begin{array}{c}0.000 \\
-0.71\end{array}$ & $\begin{array}{c}0.000 \\
-1.1\end{array}$ \\
\hline MVE & & $\begin{array}{c}-0.295 \\
(6.01)^{* * *}\end{array}$ & & & $\begin{array}{c}-0.306 \\
(6.17)^{* * * *}\end{array}$ & $\begin{array}{c}-0.309 \\
(6.23)^{* * * *}\end{array}$ & $\begin{array}{c}-0.051 \\
(1.03)\end{array}$ & $\begin{array}{c}-0.051 \\
(1.04)\end{array}$ \\
\hline VOL_MVE & & $\begin{array}{l}0.000 \\
(0.76)\end{array}$ & & & $\begin{array}{l}0.000 \\
(0.82)\end{array}$ & $\begin{array}{l}0.000 \\
(0.82)\end{array}$ & $\begin{array}{l}0.000 \\
(0.07)\end{array}$ & $\begin{array}{l}0.000 \\
(0.11)\end{array}$ \\
\hline LEVERAGE & & $\begin{array}{l}-0.181 \\
(2.26)^{* *}\end{array}$ & & & $\begin{array}{c}-0.181 \\
(2.25) * *\end{array}$ & $\begin{array}{c}-0.171 \\
(2.12)^{* *}\end{array}$ & $\begin{array}{c}0.189 \\
(1.88)^{*}\end{array}$ & $\begin{array}{c}0.175 \\
(1.75)^{*}\end{array}$ \\
\hline INFLATION & & & $\begin{array}{c}0.054 \\
(5.43)^{* * * *}\end{array}$ & & $\begin{array}{c}-0.02 \\
(2.60)^{* * * *}\end{array}$ & & $\begin{array}{c}0.053 \\
(5.26)^{* * *}\end{array}$ & \\
\hline SHTBRDEF & & & & $\begin{array}{c}0.095 \\
(5.39)^{* * *}\end{array}$ & & $\begin{array}{c}-0.048 \\
(3.62)^{* * *}\end{array}$ & & $\begin{array}{c}0.094 \\
(5.26)^{* * *}\end{array}$ \\
\hline _cons & $\begin{array}{c}1.129 \\
(6.38)^{* * * *}\end{array}$ & $\begin{array}{c}2.507 \\
(4.58)^{* * * *}\end{array}$ & $\begin{array}{c}0.782 \\
(4.14)^{* * * *}\end{array}$ & $\begin{array}{c}0.49 \\
(2.30)^{* *}\end{array}$ & $\begin{array}{c}2.795 \\
(4.98)^{* * * *}\end{array}$ & $\begin{array}{c}3.019 \\
(5.30) * * *\end{array}$ & $\begin{array}{c}1.496 \\
(2.42) * *\end{array}$ & $\begin{array}{c}1.239 \\
(1.97) * *\end{array}$ \\
\hline $\operatorname{lnsig} 2 \mathrm{u}_{\text {_cons }}$ & $\begin{array}{c}0.622 \\
(3.78)^{* * *}\end{array}$ & $\begin{array}{c}1.298 \\
(12.38) \\
* * *\end{array}$ & $\begin{array}{c}0.651 \\
(3.91)^{* * *}\end{array}$ & $\begin{array}{c}0.647 \\
(3.88)^{* * * *}\end{array}$ & $\begin{array}{c}1.302 \\
(12.39) \\
* * *\end{array}$ & $\begin{array}{c}1.308 \\
(12.46) \\
* * *\end{array}$ & $\begin{array}{c}0.675 \\
(4.05)^{* * *}\end{array}$ & $\begin{array}{c}0.673 \\
(4.02)^{* * * *}\end{array}$ \\
\hline $\mathrm{N}$ & 5077 & 5077 & 5077 & 5077 & 5077 & 5077 & 5077 & 5077 \\
\hline
\end{tabular}

Note: Standard errors in parentheses: ${ }^{* *} p<0.01,{ }^{* *} p<0.05,{ }^{*} p<0.1$. Source: Authors' analyses.

Table 7. Model performance measures for GFC (2007-2009).

\begin{tabular}{ccccccccc}
\hline Measure & Model 1 & Model 2 & Model 3 & Model 4 & Model 5 & Model 6 & Model 7 & Model 8 \\
\hline ROC & 0.9061 & 0.6041 & 0.9075 & 0.9072 & 0.5888 & 0.5962 & 0.9073 & 0.9071 \\
-2 Log Likelihood & 736 & 1201 & 730 & 731 & 1199 & 1197 & 730 & 731 \\
Cox and Snell's $R^{2}$ & 0.264 & 0.01 & 0.267 & 0.266 & 0.011 & 0.013 & 0.266 & 0.266 \\
${\text { Nagelkerke's } R^{2}}^{0.489}$ & 0.019 & 0.495 & 0.494 & 0.021 & 0.024 & 0.494 & 0.494 \\
\hline
\end{tabular}

Source: Authors' analyses.

Table 8. Model performance measures for post-GCD (2010-2017).

\begin{tabular}{ccccccccc}
\hline Measure & Model 1 & Model 2 & Model 3 & Model 4 & Model 5 & Model 6 & Model 7 & Model 8 \\
\hline ROC & 0.9379 & 0.682 & 0.9395 & 0.9394 & 0.682 & 0.6813 & 0.9384 & 0.9385 \\
-2 Log likelihood & 3154.15 & 5473.52 & 3125.7 & 3125.04 & 5465.1 & 5462.87 & 3121.37 & 3120.03 \\
Cox and Snell's $R^{2}$ & 0.418 & 0.08 & 0.422 & 0.421 & 0.082 & 0.082 & 0.421 & 0.422 \\
${\text { Nagelkerke's } R^{2}}^{0.608}$ & 0.117 & 0.613 & 0.613 & 0.119 & 0.12 & 0.613 & 0.612 \\
\hline
\end{tabular}

Source: Authors' analyses.

Any discussion of the corporate financial distress of listed firms in international exchanges would be incomplete without the presentation of an analysis at the industry level because of different levels of risks associated with the listings. Listed firms are then divided into ten different sectors, as classified by the Global Industry Classification Standard (GICS), and their observations are also classified into three levels of financial distress based on a modified Distance-to-Default (DD) model, as presented in Table 9.

The highest risk industry belongs to Consumer Staples, which includes Food \& Staples Retailing, Household \& Personal Products, and Food Beverage \& Tobacco, with a 59.6 percent indicator of financial distress (that is, in the Grey or Bankruptcy zones). Utilities, Consumer Discretionary, and Energy is a relatively high-risk industry, with an indicator of financial distress of approximately 
50 percent. In contrast, the lowest exposure industry belongs to the Health \& Education sector, with an indicator of financial distress of 33.8 per cent.

Tables 10 and 11 report the results of the DD analysis for both periods. It is noticeable that the GFC had a damaging impact in each sector. Table 10 shows that almost all the sectors have higher financial risks, with the probability of default (that is, in the Grey or Bankruptcy zones) being nearly 50 percent higher during the GFC than the post-GFC period. The highest bankruptcy rate is the Health \& Education (at 80 per cent) industry, while the lowest bankruptcy rate belongs to Utilities (at 38.2 per cent) during the GFC.

Table 11 provides the probability of distress in the post-GFC period, which indicates a tendency to decline sharply in all the sectors, except for the Utilities sector. The Health \& Education sector demonstrates the most impressive recovery in the post-GFC period, with the probability of default decreasing substantially from around 80 percent to 20 percent as a result of the use of modern technology.

On the other hand, the Utilities sector, which includes Residential \& Industrial Electrics, Water, and Gas \& Oil, recorded a dramatic increase in the bankruptcy rate in the post-GFC period. During the GFC, the sector had the lowest risk among all the sectors. It is worth noting that the sector is dominated by state-owned firms that are financially funded directly by the Vietnam Government. However, the loss of economic stimulus packages from the Vietnam Government, together with the strong equitability trend of the state-owned companies, are crucial factors in the sharp increases in the bankruptcy rate during the post-GFC period, with the highest bankruptcy rate of 63.8 percent. Detailed marginal effects are presented at Appendices $C$ and $D$ of the paper.

Table 9. Overall Distance to Default in all sectors for the full sample (2007-2017).

\begin{tabular}{llrrc}
\hline \multicolumn{1}{c}{ Sector } & No. of Observations & Safe & Grey & Bankruptcy \\
\hline Energy & 319 & $41.4 \%$ & $6.6 \%$ & $52.0 \%$ \\
Materials & 885 & $47.2 \%$ & $5.2 \%$ & $47.6 \%$ \\
Industrials & 2596 & $47.1 \%$ & $5.5 \%$ & $47.5 \%$ \\
Consumer Discretionary & 484 & $46.9 \%$ & $6.8 \%$ & $46.3 \%$ \\
Consumer Staples & 911 & $40.4 \%$ & $7.0 \%$ & $52.6 \%$ \\
Health \& education & 176 & $62.5 \%$ & $3.4 \%$ & $34.1 \%$ \\
Financials & 882 & $49.2 \%$ & $4.3 \%$ & $46.5 \%$ \\
Technology & 115 & $51.3 \%$ & $5.2 \%$ & $43.5 \%$ \\
Telecommunication & 104 & $53.8 \%$ & $2.9 \%$ & $43.3 \%$ \\
Utilities & 139 & $41.2 \%$ & $7.6 \%$ & $51.1 \%$ \\
Total & 6611 & & & \\
\hline
\end{tabular}

Source: Authors' analyses.

Table 10. Overall Distance to Default in all sectors for GFC (2007-2009).

\begin{tabular}{lcccc}
\hline \multicolumn{1}{c}{ Sector } & No. of Observations & Safe & Grey & Bankruptcy \\
\hline Energy & 73 & $38.4 \%$ & $12.3 \%$ & $49.3 \%$ \\
Materials & 197 & $42.6 \%$ & $5.1 \%$ & $52.3 \%$ \\
Industrials & 646 & $42.0 \%$ & $6.0 \%$ & $52.0 \%$ \\
Consumer Discretionary & 115 & $37.4 \%$ & $8.7 \%$ & $53.9 \%$ \\
Consumer Staples & 229 & $40.2 \%$ & $8.3 \%$ & $51.5 \%$ \\
Health \& education & 50 & $20.0 \%$ & $8.0 \%$ & $72.0 \%$ \\
Financials & 163 & $49.1 \%$ & $3.7 \%$ & $47.2 \%$ \\
Technology & 31 & $35.5 \%$ & $6.5 \%$ & $58.1 \%$ \\
Telecommunication & 27 & $33.3 \%$ & $7.4 \%$ & $59.3 \%$ \\
Utilities & 34 & $61.8 \%$ & $17.6 \%$ & $20.6 \%$ \\
Total & 1565 & & & \\
\hline
\end{tabular}


Table 11. Overall Distance to Default in all sectors for post-GFC (2010-2017).

\begin{tabular}{lcccc}
\hline \multicolumn{1}{c}{ Sector } & No. of Observations & Safe & Grey & Bankruptcy \\
\hline Energy & 246 & $42.3 \%$ & $4.9 \%$ & $52.8 \%$ \\
Materials & 688 & $48.5 \%$ & $5.2 \%$ & $46.2 \%$ \\
Industrials & 1950 & $48.8 \%$ & $5.3 \%$ & $45.9 \%$ \\
Consumer Discretionary & 369 & $49.9 \%$ & $6.2 \%$ & $43.9 \%$ \\
Consumer Staples & 682 & $40.5 \%$ & $6.6 \%$ & $52.9 \%$ \\
Health \& education & 126 & $79.4 \%$ & $1.6 \%$ & $19.0 \%$ \\
Financials & 719 & $49.2 \%$ & $4.5 \%$ & $46.3 \%$ \\
Technology & 84 & $57.1 \%$ & $4.8 \%$ & $38.1 \%$ \\
Telecommunication & 77 & $61.0 \%$ & $1.3 \%$ & $37.7 \%$ \\
Utilities & 105 & $36.2 \%$ & $5.7 \%$ & $58.1 \%$ \\
Total & 5056 & & & \\
\hline
\end{tabular}

Source: Authors' analyses.

The financial sector has been predicted to remain stable after the GFC. The financial distress has decreased slightly - by around one percent. The root cause of serious distress is primarily the poor performance of the banking system. It should be stressed that almost all commercial banks were heavily affected by the GFC, as well as the restructuring of the banking system by government policymakers.

The Basel II Accord is a set of international banking standards derived from the Basel Committee on Banking Supervision (BCBS). Basel II improves on Basel I by requiring large cash reserves from commercial banks to cover potential risks. Applying Basel II for commercial banks provides ample evidence of the tightening of risky behavior relating to bank management. Several inherent weaknesses of commercial banks could be discovered after the GFC led to the M\&A action among banks. To ensure the safety of the banking system, the State Bank of Vietnam (SBV) has decided to apply special controls to commercial banks that have a high rate of non-performing loans (NLPs).

\section{Concluding Remarks and Policy Implications}

Numerous studies have been conducted over the last four decades regarding the relationships underlying corporate financial distress. Any discussion of the corporate financial distress of listed firms in international exchanges would be incomplete without a critical analysis at the industry level, because of the different levels of risk among the industries. In this paper, listed firms were divided into ten different sectors, as classified by the Global Industry Classification Standard (GICS).

The paper considered the financial distress of Vietnamese listed firms at the industry level during the last decade. To consider the changes, if any, on the level of corporate financial distress in Vietnam, two distinct periods were considered, namely the period of the Global Financial Crisis (GFC) (2007-2009) and the post-GFC period (2010-2017). A logit regression technique was used for empirical estimation. Several alternative models were used to consider the separate effects arising from accounting and market-based factors. An extension of the model in the paper included an analysis of selected macroeconomic factors that affected the corporate financial distress of listed firms in any international exchange at the industry level in Vietnam, including Inflation and the Short-term one-year rate.

In general, the empirical findings from the paper confirmed that the corporate financial distress prediction model of Vietnamese listed firms at the industry level, which includes accounting factors with macroeconomic indicators, appeared to perform much better than did the financial distress model comprising market-based factors with macroeconomic fundamentals.

In addition, the empirical findings presented evidence to confirm that the GFC had a destructive impact on each sector. Almost all sectors of the Vietnam economy had financial risk that was approximately 50 percent higher during the GFC period than in the post-GFC period. Of all the sectors in Vietnam, the highest bankruptcy rate was found to be in the Health \& Education sector (at 80 per cent), while the lowest risk was found in the Utilities (at 38.2 per cent) during the GFC period. 
For the post-GFC period, the probability of distress showed a tendency to decline sharply for all sectors of the Vietnam economy, except for the Utility sector. The Health \& Education sector demonstrated the most impressive recovery after the GFC, where the probability of default decreased from approximately 80 percent during the GFC period (2007-2009) to around 20 percent for the post-GFC period (2010-2017).

The Utilities sector recorded a dramatic increase in bankruptcies after the GFC. During the GFC period, the sector had the lowest risk among all the sectors. It is worth noting that the sector is dominated by state-owned firms that are financially funded directly by the Vietnam Government. In addition, the Financial sector is likely to remain stable after the GFC.

The empirical findings provide additional evidence for the Vietnam Government, as well as those from other emerging markets, to examine and evaluate the risk of the corporate financial distress of listed firms in any international exchange, especially at the industry level. For the case of Vietnam, Utilities should receive special attention as the sector exhibits a high level of risk without adequate support from the Government. Any reform of this sector, without an accompanying comprehensive analysis of risk, will carry a significant level of risk, which would be likely to flow on to the economy as the whole.

In marked contrast, the Financial sector appeared to be strong, both during and after the GFC. This observation confirms the robustness of the existing regulatory framework for the banking sector in Vietnam.

Author Contributions: Conceptualization, B.N.V.P. and D.H.V.; methodology, B.N.V.P. and D.H.V.; software, B.N.V.P.; validation, B.N.V.P., D.H.V. and M.M.; formal analysis, B.N.V.P.; investigation, B.N.V.P. and C.M.H.; resources, D.H.V.; data curation, B.N.V.P. and C.M.H.; writing-original draft preparation, B.N.V.P.; writing-review and editing, D.H.V. and M.M.; visualization, D.H.V. and M.M.; supervision, D.H.V.; project administration, C.M.H.; funding acquisition, D.H.V. and M.M.

Funding: This research received no external funding. APC was funded by HCMC Open University.

Acknowledgments: The authors are most grateful for the helpful comments and suggestions of three reviewers. For financial support, the authors thank Ho Chi Minh City Open University Vietnam. The fourth author wishes to acknowledge the Australian Research Council and Ministry of Science and Technology (MOST), Taiwan.

Conflicts of Interest: The authors declare no conflict of interest. 


\section{Appendix A}

Table A1. Correlation matrix during crisis, 2007-2009.

\begin{tabular}{|c|c|c|c|c|c|c|c|c|c|c|}
\hline Variable & WCTA & RETA & EBITTA & BVETL & PRICE & MVE & VOL_MVE & LEVERAGE & INFLATION & SHTBRDEF \\
\hline WCTA & 1 & & & & & & & & & \\
\hline RETA & $0.179^{* * *}$ & 1 & & & & & & & & \\
\hline EBITTA & $0.1327^{* * *}$ & $0.4286^{* * *}$ & 1 & & & & & & & \\
\hline BVETL & $0.311^{* * *}$ & $0.3292 * * *$ & $0.2256^{* * *}$ & 1 & & & & & & \\
\hline PRICE & 0.0252 & $0.2473^{* * *}$ & $0.0409 *$ & 0.0009 & 1 & & & & & \\
\hline MVE & $-0.0676^{* * *}$ & $0.1801^{* * *}$ & $0.0614^{* *}$ & 0.0153 & $0.4606^{* * *}$ & 1 & & & & \\
\hline VOL_MVE & -0.0319 & 0.0265 & $0.0532 * *$ & 0.0352 & 0.0018 & $0.1522^{* * *}$ & 1 & & & \\
\hline LEVERAGE & $0.1501^{* * *}$ & $0.3271^{* * *}$ & $0.1655^{* * *}$ & $0.4815^{* * *}$ & $0.4028^{* * *}$ & $0.5012 * * *$ & $0.1654^{* * *}$ & 1 & & \\
\hline SHTBRDEF & -0.0093 & $-0.0541 * *$ & 0.0252 & 0.0014 & $-0.3355^{* * *}$ & $-0.1446^{* * *}$ & 0.0197 & $-0.1874^{* * *}$ & $0.8445^{* * *}$ & 1 \\
\hline
\end{tabular}

Notes: WCTA (working capital over total assets), RETA (retained earnings over total assets), EBITTA (earnings before interest and taxes [operating profit] to total assets), BVETA (book value of equity to total liabilities), MVE (market value of equity), PRICE (stock price), VOL_MVE (volatility of market value of equity), LEVERAGE (leverage ratio), INFLATION (inflation), and SHTBRDEF (short-term one-year rate), ${ }^{* * *} p<0.01,{ }^{* *} p<0.05, * p<0.1$

\section{Appendix B}

Table A2. Correlation matrix post crisis, 2010-2017.

\begin{tabular}{|c|c|c|c|c|c|c|c|c|c|c|}
\hline Variable & WCTA & RETA & EBITTA & BVETL & PRICE & MVE & VOL_MVE & LEVERAGE & INFLATION & SHTBRDEF \\
\hline WCTA & 1 & & & & & & & & & \\
\hline RETA & $0.4308^{* * *}$ & 1 & & & & & & & & \\
\hline EBITTA & $0.1529 * * *$ & $0.2529 * * *$ & 1 & & & & & & & \\
\hline PRICE & $0.1909^{* * *}$ & $0.3431^{* * *}$ & $0.184^{* * *}$ & $0.1787^{* * *}$ & 1 & & & & & \\
\hline MVE & $0.0679 * * *$ & $0.326^{* * *}$ & $0.1105^{* * *}$ & $0.0951^{* * *}$ & $0.4618^{* * *}$ & 1 & & & & \\
\hline VOL_MVE & -0.0117 & 0.0167 & 0.0124 & 0.0223 & $0.0624^{* * *}$ & $0.2053^{* * *}$ & 1 & & & \\
\hline LEVERAGE & $0.3091^{* * *}$ & $0.2879 * * *$ & $0.1927^{* * *}$ & $0.5721^{* * *}$ & $0.3882 * * *$ & $0.3435^{* * *}$ & $0.2126^{* * *}$ & 1 & & \\
\hline SHTBRDEF & $0.0316^{*}$ & $0.119^{* * *}$ & $0.0494^{* * *}$ & $0.029 * *$ & $0.0648^{* * *}$ & $0.0576^{* * *}$ & 0.0007 & 0.0015 & 0.91 & 1 \\
\hline
\end{tabular}

Notes: WCTA (working capital over total assets), RETA (retained earnings over total assets), EBITTA (earnings before interest and taxes [operating profit] to total assets), BVETA (book value of equity to total liabilities), MVE (market value of equity), PRICE (stock price), VOL_MVE (volatility of market value of equity), LEVERAGE (leverage ratio), INFLATION (inflation), and SHTBRDEF (short-term one-year rate), ${ }^{* * *} p<0.01, * * 0<0.05,{ }^{*} p<0.1$. 


\section{Appendix C}

Table A3. Marginal effect post crisis, 2007-2009.

\begin{tabular}{ccccccccc}
\hline Variable & Model 1 & Model 2 & Model 3 & Model 4 & Model 5 & Model 6 & Model 7 & Model 8 \\
\hline WCTA & -0.000075 & & -0.000346 & -0.000329 & & & -0.000414 & -0.000432 \\
RETA & -0.009701 & & -0.008298 & -0.007984 & & & -0.006677 & -0.006901 \\
EBITTA & -0.248119 & & -0.215074 & -0.228503 & & & -0.211114 & -0.222159 \\
BVETL & 0.000428 & & 0.000332 & 0.000370 & & & 0.000389 & 0.000408 \\
PRICE & & 0.000000 & & & 0.000000 & 0.000000 & 0.000000 & 0.000000 \\
MVE & & 0.005573 & & & 0.005721 & 0.004832 & -0.000115 & -0.000143 \\
VOL_MVE & & 0.000000 & & & 0.000000 & 0.000000 & 0.000000 & 0.0000000 \\
LEVERAGE & & -0.009482 & & & -0.008831 & -0.007280 & -0.000057 & -0.000025 \\
INFLATION & & & 0.000084 & & 0.001244 & & 0.000076 & \\
SHTBRDEF & & & & 0.000220 & & 0.004788 & & 0.000208 \\
\hline
\end{tabular}

Note: See variable definitions in notes to Appendix A.

\section{Appendix D}

Table A4. Marginal effect post crisis, 2010-2017.

\begin{tabular}{ccccccccc}
\hline Variable & Model 1 & Model 2 & Model 3 & Model 4 & Model 5 & Model 6 & Model 7 & Model 8 \\
\hline WCTA & -0.018123 & & -0.016384 & -0.016199 & & & -0.016074 & -0.015689 \\
RETA & -0.052113 & & -0.056582 & -0.057523 & & & -0.052396 & -0.051922 \\
EBITTA & -3.608555 & & -3.439809 & -3.431021 & & & -3.432932 & -3.394622 \\
BVETL & -0.012977 & & -0.012338 & -0.012458 & & & -0.018062 & -0.017669 \\
PRICE & & -0.000004 & & & -0.000004 & -0.000004 & 0.000000 & 0.000000 \\
MVE & & -0.036388 & & & -0.037685 & -0.038076 & -0.000942 & -0.000941 \\
VOL_MVE & & 0.000000 & & & 0.000000 & 0.000000 & 0.000000 & 0.000000 \\
LEVERAGE & & -0.022332 & & & -0.022296 & -0.021023 & 0.003504 & 0.003213 \\
INFLATION & & & 0.000997 & & -0.002463 & & 0.000980 & \\
SHTBRDEF & & & 0.001754 & & -0.005968 & & 0.001714 \\
\hline
\end{tabular}

Note: See variable definitions in notes to Appendix A.

\section{References}

Agarwal, Vineet, and Richard Taffler. 2008. Comparing the performance of market-based and accounting-based bankruptcy prediction models. Journal of Banking E Finance 32: 1541-51.

Agrawal, Khushbu, Yogesh Maheshwari, S. Khilji, and L. Swinkels. 2016. Predicting financial distress: Revisiting the option-based model. South Asian Journal of Global Business Research 5: 268-84. [CrossRef]

Ali, Asghar, and Kevin Daly. 2010. Macroeconomic determinants of credit risk: Recent evidence from a cross-country study. International Review of Financial Analysis 19: 165-71. [CrossRef]

Allen, David Edmund, and Robert Powell. 2012. The fluctuating default risk of Australian banks. Australian Journal of Management 37: 297-325. [CrossRef]

Allen, David Edmund, Ray Boffey, and Robert J. Powell. 2011. Peas in a Pod: Canadian and Australian Banks before and during a Global Financial Crisis. Available online: https://ssrn.com/abstract=1884084 (accessed on 13 August 2019).

Altman, Edward I. 1968. Financial ratios, discriminant analysis and the prediction of corporate bankruptcy. Journal of Finance 23: 589-609. [CrossRef]

Altman, Edward I. 2000. Predicting Financial Distress of Companies: Revisiting the Z-Score and ZETA Models. New York: Stern School of Business, New York University.

Altman, Edward I. 2005. An emerging market credit scoring system for corporate bonds. Emerging Markets Review 6: 311-23. [CrossRef]

Altman, Edward I., Robert G. Haldeman, and Paul Narayanan. 1977. Zeta to analyse a new model to identify bankruptcy risk of corporations. Journal of Banking E Finance 1: 29-54.

Asquith, Paul, Robert Gertner, and David Scharfstein. 1994. Anatomy of financial distress: An examination of junk-bond issuers. Quarterly Journal of Economics 109: 625-58. [CrossRef]

Badar, Munib, and Yasmin Javid. 2013. Impact of macroeconomic forces on nonperforming loans: An empirical study of commercial banks in Pakistan. WSEAS Transactions on Business and Economics 10: 40-48. 
Beaver, William H. 1966. Financial ratios as predictors of failure. Journal of Accounting Research 4: 71-111. [CrossRef] Beaver, William H., Maureen F. McNichols, and Jung-Wu Rhie. 2005. Have financial statements become less informative? Evidence from the ability of financial ratios to predict bankruptcy. Review of Accounting Studies 10: 93-122. [CrossRef]

Bharath, Sreedhar T., and Tyler Shumway. 2008. Forecasting default with the Merton distance to default model. Review of Financial Studies 21: 1339-69. [CrossRef]

Black, Fischer, and Myron Scholes. 1973. The pricing of options and corporate liabilities. Journal of Political Economy 81: 637-54. [CrossRef]

Byström, Hans Ne. 2006. Merton unraveled: A flexible way of modeling default risk. Journal of Alternative Investments 8: 39-47.

Byström, Hans, Lugkana Worasinchai, and Srisuda Chongsithipol. 2005. Default risk, systematic risk and Thai firms before, during and after the Asian crisis. Research in International Business and Finance 19: 95-110. [CrossRef]

Chaibi, Hasna, and Zied Ftiti. 2015. Credit risk determinants: Evidence from a cross-country study. Research in International Business and Finance 33: 1-16. [CrossRef]

Charitou, Andreas, Dionysia Dionysiou, Neophytos Lambertides, and Lenos Trigeorgis. 2013. Alternative bankruptcy prediction models using option-pricing theory. Journal of Banking E Finance 37: 2329-41.

Chava, Sudheer, and Robert A. Jarrow. 2004. Bankruptcy prediction with industry effects. Review of Finance 8: 537-69. [CrossRef]

Cox, David Roxbee, and Joyce J. Snell. 1989. The Analysis of Binary Data, 2nd ed. London: Chapman and Hall.

Crosbie, Peter, and Jeffrey Bohn. 2003. Modelling Default Risk. Available online: http://www.moodyskmv.com/ research/files/wp/ModelingDefaultRisk.pdf (accessed on 13 August 2019).

Ćurak, Marijana, Sandra Pepur, and Klime Poposki. 2013. Determinants of non-performing loans-evidence from Southeastern banking systems. Banks \& Bank System 8: 45-54.

Delianedis, Gordon, and Robert L. Geske. 2003. Credit risk and risk-neutral default probabilities: Information about rating migrations and defaults. Paper presented at the EFA 2003 Annual Conference, Glasgow, UK, August 20-23.

Demirgüç-Kunt, Asli, and Enrica Detragiache. 1998. The determinants of banking crises in developing and developed countries. Staff Papers 45: 81-109. [CrossRef]

Hillegeist, Stephen A., Elizabeth K. Keating, Donald P. Cram, and Kyle G. Lundstedt. 2004. Assessing the probability of bankruptcy. Review of Accounting Studies 9: 5-34. [CrossRef]

Koutsomanoli-Filippaki, Anastasia, and Emmanuel Mamatzakis. 2009. Performance and Merton-type default risk of listed banks in the EU: A panel VAR approach. Journal of Banking E Finance 33: 2050-61.

Leland, Hayne. 2002. Predictions of expected default frequencies in structural models of debt. Paper presented at the Venice Conference on Credit Risk, Venice, Italy, September 8.

Lopez, Jose A. 2004. The empirical relationship between average asset correlation, the firm probability of default, and asset size. Journal of Financial Intermediation 13: 265-83. [CrossRef]

Mare, Davide Salvatore. 2015. Contribution of macroeconomic factors to the prediction of small bank failures. Journal of International Financial Markets, Institutions and Money 39: 25-39. [CrossRef]

Merton, Robert C. 1974. On the pricing of corporate debt: The risk structure of interest rates. Journal of Finance 29: 449-70.

Nagelkerke, Nico J. 1991. A note on a general definition of the coefficient of determination. Biometrika 78: 691-92. [CrossRef]

Ohlson, James A. 1980. Financial ratios and the probabilistic prediction of bankruptcy. Journal of Accounting Research 18: 109-31. [CrossRef]

Patel, Kanak, and Prodromos Vlamis. 2006. An empirical estimation of default risk of the UK real estate companies. The Journal of Real Estate Finance and Economics 32: 21-40. [CrossRef]

Pham, Binh, Trung Do, and Duc Vo. 2018. Financial distress and bankruptcy prediction: An appropriate model for listed firms in Vietnam. Economic Systems 2: 616-24. [CrossRef]

Pindado, Julio, Luis Rodrigues, and Chabelade la Torre. 2008. Estimating financial distress likelihood. Journal of Business Research 61: 995-1003. [CrossRef]

Rees, Bill. 1995. Financial Analysis. London: Prentice Hall. 
Rinaldi, Laura, and Alicia Sanchis-Arellano. 2006. Household Debt Sustainability: What Explains Household Non-Performing Loans? An Empirical Analysis. Rinaldi, Laura and Sanchis-Arellano, Alicia, Household Debt Sustainability: What Explains Household Non-Performing Loans? An Empirical Analysis (January 2006). ECB Working Paper No. 570. Available online: https://ssrn.com/abstract $=872528$ (accessed on 13 August 2019).

Shumway, Tyler. 2001. Forecasting bankruptcy more accurately: A simple hazard model. Journal of Business 74: 101-24. [CrossRef]

Stanisic, Nemanja, Vule Mizdrakovic, and Goranka Knezevic. 2013. Corporate bankruptcy prediction in the Republic of Serbia. Industrija 41: 145-59.

Taffler, Richard J. 1984. Empirical models for the monitoring of UK corporations. Journal of Banking $\mathcal{E}$ Finance 8: 199-227.

Theodossiou, Panayiotis. 1991. Alternative models for assessing the financial condition of business in Greece. Journal of Business Finance \& Accounting 18: 697-720.

Tinoco, Mario Hernandez, and Nick Wilson. 2013. Financial distress and bankruptcy prediction among listed companies using accounting, market, and macroeconomic variables. International Review of Financial Analysis 30: 394-419. [CrossRef]

Trujillo-Ponce, Antonio, Reyes Samaniego-Medina, and Clara Cardone-Riportella. 2014. Examining what best explains corporate credit risk: Accounting-based versus market-based models. Journal of Business Economics and Management 15: 253-76. [CrossRef]

Uğurlu, Mine, and Hakan Aksoy. 2006. Prediction of corporate financial distress in an emerging market: The case of Turkey. Cross Cultural Management: An International Journal 13: 277-95. [CrossRef]

Vasicek, Oldrich A. 1984. Credit Valuation: KMV Corporation. Available online: http://www.ressourcesactuarielles. net/EXT/ISFA/1226.nsf/0/c181fb77ee99d464c125757a00505078/\$FILE/Credit_Valuation.pdf (accessed on 13 August 2019).

Vassalou, Maria, and Yuhang Xing. 2004. Default risk in equity returns. Journal of Finance 59: 831-68. [CrossRef]

Whitaker, Richard B. 1999. The early stages of financial distress. Journal of Economics and Finance 23: 123-32. [CrossRef]

World Bank. 2016. GDP (Current US\$). Available online: http://data.worldbank.org/indicator/NY.GDP.MKTP.CD/ (accessed on 13 August 2019).

Wu, Yanhui, Clive Gaunt, and Stephen Gray. 2010. A comparison of alternative bankruptcy prediction models. Journal of Contemporary Accounting \& Economics 6: 34-45.

Zhang, Benjamin Yibin, Hao Zhou, and Haibin Zhu. 2009. Explaining credit default swap spreads with the equity volatility and jump risks of individual firms. Review of Financial Studies 22: 5099-131. [CrossRef]

Zmijewski, Mark E. 1984. Methodological issues related to the estimation of financial distress prediction models. Journal of Accounting Research 22: 59-82. [CrossRef]

(C) 2019 by the authors. Licensee MDPI, Basel, Switzerland. This article is an open access article distributed under the terms and conditions of the Creative Commons Attribution (CC BY) license (http://creativecommons.org/licenses/by/4.0/). 